\title{
LAW AND FAITH IN ANCIENT ISRAEL AND IN MODERN DEMOCRATIC STATEHOOD AS SEARCH FOR SOCIO-POLITICAL WELLBEING
}

\author{
Christo Lombaard \\ Practical Theology and Missiology \\ University of Pretoria
}

\begin{abstract}
In this contribution, the argument pits two cultural reflexes against one another. In modern democracies, religion is removed from the socio-political sphere; in ancient Israel, religion was inserted into the socio-political sphere. In both cases, the intention was the same: the socio-political wellbeing of the citizenry. Such a cultural comparison puts to question the false assumption in modern democracies, that a public sphere emptied of religion constitutes greater freedom.
\end{abstract}

Keywords: Relationship between law and faith; Sacralisation; Secularisation; Cultural relativity; Freedom

\section{Provenance}

Based on the invited 2016 Annual Oration: Pilgrim Uniting Church, Adelaide, Australia and the Research Unit for the Study of Society, Law and Religion, University of Adelaide in Australia, this contribution further develops a trajectory of investigation that brings into dialogue aspects of ancient Israelite society, as reflected in the Hebrew Bible, and aspects of modern democratic statehood ${ }^{1}$. Within both of these (historically related) societies, based on metaphysics that are unrelated only when viewed superficially, a search for socio-political wellbeing is undertaken by means of certain implicit driving forces in society. These formative potencies are based on the respective metaphysics, which are the aspects of the two societies that are in this contribution placed in association with one another. Through such a phenomenological mirroring of sorts, the validity of the quest for the wellbeing of the citizenry by means of these socio-political driving forces, most formally constituted by law, can in current democratic societies be indicated.

To adapt a Shakespearean metaphor (from As You Like It, Act II, Scene VII, Line 139), the way in which God is staged in public influences reflexively the ways in which socio-political wellbeing is viewed. Put differently, the dominant metaphysics of a society leads it almost instinctively towards certain outlines, at least, of possible sociopolitical ordering possibilities that would constitute a good society in which to live. Happiness (not to be confused with superficial "fun" but for the purposes here understood as a just and fair society in which people live well; cf. Verhoef 2014:537546 ) is pursued by ordering a society in certain ways, also politically. This ordering is

I also gratefully acknowledge the foundational influence of the small circle interdisciplinary meetings on my thoughts here. 
always related to metaphysical orientations (Schmitt 1922 [1934], Schmitt 1970 [2008]; cf. Lombaard 2019:1-6). The latter connection has, however, in the public ordering of institutions, such as the political and legal and economic spheres of society in specifically modern democracies, been carefully disowned. Disingenuously so, as will be indicated below.

Though the socio-political wellbeing of a citizenry and the accompanying implicit metaphysical orientation, as its corollary, cannot be said to be linked in any deterministic manner, as if the one would logically necessitate the other, they are certainly not unrelated to one another. The latter facilitative or enabling link is to a great extent invisible in the day-to-day living of life in all its overwhelming dimensions. In liberal (here meant in its classical sense: freedom-oriented) Western-style democracies, that link is, however, often explicitly forsworn. Conversely, though, inasmuch as day-to-day life is constituted foundationally by money (Marx), sex (Freud) and power (Nietzsche, Foucault), whether acknowledged or not, in both private and public life, the same applies to faith. The latter is meant not as a pious confession but as a phenomenological trait of common life. It remains remarkable, however, that the active influence of the latter of these impulses - religiosity - seems at times so difficult to accept by leadership that reflexively assume the operational power of the other impulses. This, the more so within otherwise self-analytical liberal Western-style democracies - regarded by many as a pinnacle of political systems thus far designed within humanity, precisely because of its inherent rationality of self-critical scrupulousness.

The relationship between matters of law and matters of faith is differently constituted in various societies, though, with uniquenesses and commonalities which ought always to be weighed. Perhaps it is apt, therefore, that this contribution was authored on three continents: in Australia (specifically in Adelaide), in Africa (specifically in Pretoria, South Africa) and in Europe (specifically in Tallinn, Estonia). However, our blindnesses on these matters at times outweigh what we overconfidently see. I therefore present what is below more as an invitation to other thinkers to take us yet further, rather than as an answer.

\section{Providence}

One of the problems with theologians pronouncing themselves on "The Bible and..." topics is a covert kind of moralism that often goes along with the exercise, namely that in some way the Bible is meant to teach us something for today. Such a kind of moralism, akin to when little lessons for edification are extracted from tales for children, is objectionable in engagements with the biblical texts for many reasons, not the least of which is what has become known as the problem of history (cf. le Roux 1993:35-63). The latter includes that the vast differences between the ancient and modern worlds are such that "der garstig breite Graben", already formulated as such by Lessing in 1777 (1979:13), is so dramatic as to bedevil any kind of modern "application" of these ancient texts. What Joas (2013:3) calls "the interleaving of genesis and validity" remains a road which, like the one to hell in the famous aphorism, is paved with good intensions. It is no wonder that the discipline of philosophical hermeneutics (cf. Thiselton 1992 for a foundational historical overview) finds its intellectual cradle in the theological problem of the heartfelt necessity to bridge this "frighteningly expansive trough of history" (to offer a loose translation of the Lessing 1777 / 1979:13 quote above) - the eternal problem 
of relevance.

This incentive towards renewed relevance is evidently present already within the Bible texts themselves, leading to intense redactional activities, of both a revisionary kind (expanding, truncating or reframing the texts) and of a contestatory nature (texts answering texts by means of re-editing or by offering counter-theologies). However, the nature of the historical contingency of our human existence is such that the modern contextualising optimism which differentiates between an understanding of the past and an application to the present holds to an impossible distinction (le Roux 1997:410-416, 419): the one implies the other, always, immediately and inherently.

This kind of historical approach to the texts of the Bible precludes any easy moralisms, lessons or messages to be drawn from the Bible for our time. However, an overtly historical approach to the Bible, which holds the greatest legitimacy for reading these texts (cf. Lombaard 2008:49-62), does enable cultural-phenomenological comparisons, in which similarities and differences between parallel occurrences in disparate contexts may be noted, and perhaps historical influences or analogous reverberations traced. These relate as much to the phenomenon of faith as to any other aspect of the human condition ${ }^{2}$, namely with religiosity as part of the collective evolutionary armoury of homo sapiens (cf. van Huyssteen 2006). Insights gained from such comparison may well prove instructive, but then not in any moralistic sense. Rather, perspective may be gained on historical, sociological, legal and other contingencies in which we find ourselves immersed. Such relativising perspectives may lead to insecurities (which are intellectually and spiritually healthy, yet which entrenched institutions tend to dislike, as their received truths become infirm), and for that reason may well lead us to search for different, one hopes better ways of being society.

One way in which being a society that works well, namely one that facilitates sustainable measures of harmony and happiness (Atherton, Graham and Steedman 2011; Csikszentmihalyi 1990), may be promoted, is to further "wellbeing". As vague a concept as many in the Humanities are (cf. Gullone and Cummins 2002:5-6), here that term ${ }^{3}$ is intended to refer less to its oft-employed individual senses (as in e.g. Dodge, Daly, Huyton and Sanders 2012:222-235) and more to socio-political co-existence. Wellbeing on such a socio-political niveau is therefore here understood as a sense (perhaps always

\footnotetext{
The influence of historical consciousness on matters of faith is thus not the impulse to turn inward only, "into the soul", as it were, in an attempt at escaping our intellectual reality - cf. Boer 2007:402. Other possibilities exist too, one of which is argued here.

3 Studying aspects of wellbeing is certainly in vogue at present, as the recent six-volume Wiley Blackwell series demonstrates:

- $\quad$ Landry, Susan and Cooper, Cary (eds). 2014. Wellbeing: A complete reference guide. Volume I: Wellbeing in children and families. Chichester: Wiley Blackwell.

- Cooper, Rachel, Burton, Elizabeth and Cooper, Cary (eds) 2014. Wellbeing: A complete reference guide. Volume II: Wellbeing and the environment. Chichester: Wiley Blackwell.

- Chen, Peter and Cooper, Cary (eds) 2014. Wellbeing: A complete reference guide. Volume III: Work and wellbeing. Chichester: Wiley Blackwell.

- $\quad$ Kirkwood, Thomas Cooper, Cary (eds) 2014. Wellbeing: A complete reference guide. Volume IV: Wellbeing in Later Life. Chichester: Wiley Blackwell.

- McDaid, David and Cooper, Cary (eds) 2014. Wellbeing: A complete reference guide. Volume V: The economics of wellbeing. Chichester: Wiley Blackwell.

- Huppert, Felicia and Cooper, Cary (eds) 2014. Wellbeing: A complete reference guide. Volume VI: Interventions and policies to enhance wellbeing. Chichester: Wiley Blackwell.
} 
elitist, and hence imposed) of how a society may best function as a relatively peaceful whole, given its constituencies and adversaries. At least a broad, though always imprecise, shared sense of identity and some measure of cohesion on basic levels of assumption are implied (on summarising the nature of social cohesion, see e.g. Fonseca, Lukosch and Brazier 2018:1-23. This form of functional togetherness within a society has been influentially explicated as forms of "capital" - symbolic, cultural and social by Bourdieu 1986:241-258). A measure of solidarity between the leadership elites (of various societal spheres) and wider society must exist to ensure the perceived social validity of the positions that take dominance within that society. This is in modern political philosophy understood as the "social contract" - an inheritance from Hobbes, Locke and Rousseau (cf. e.g. Morris 1999) still foundationally operative in modern democracies, with Rawls's A theory of justice (1971) as the most influential of such contributions in recent decades. In all these contributions, the aim is to establish, to the extent possible, the art and craft of living well together in society; i.e. our wellbeing as citizens in a modern civilisation.

In the current world, such wellbeing would in our shared political heritage, postWorld War II (and more recently, in post-Soviet countries in Europe, with varied degrees of success, and in post-apartheid South Africa, ever more flailingly), extend most naturally to liberal democracies - whose "Western" sense is currently under substantial ideological, political, economic and military pressure from different geopolitical spheres. Noticeably in recent times, the earlier-assumed ever-increasing prevalence of this form of governance has come to be questioned, given surprising turns of leadership, conspicuously by democratic means, in the USA under Trump, the UK under Johnson, Brazil under Bolsonaro, Hungary under Orbán, South Africa under Zuma, and elsewhere over the recent half a decade. The steadily rising influence of China, by no means a role model of liberal democracy, yet with economic advancement that is translated into sustained international growth in power, set to continue for the next decades, renders self-contented assumptions about liberal democracy much grounds for deeper thought. The recent return to international prominence of Russia and Turkey, as well as the political rise of religious fundamentalisms, puts the same kind of questions differently. Analogous questioning is produced by the effects of unpredictable calamities on an international scale, such as that of the 2020-2021 COVID-19 pandemic, the political effects of which include for instance a seemingly all too willing sacrifice of, at times, human rights and, at times, the usurpation of parliamentary democracy.

The remarkable liberal democratic political system, still one of the most successful in human history in number of geographies covered and in number of people affected, has as its twin core standards (cf. van der Ven, Dreyer and Pieterse 2004:11-378 for a substantial historical overview):

- freedom of choice to as great an extent as is socially feasible; and

- the protection of the rights of the individual against any encroachment, whether the source of such encroachment is other individuals, groups, and importantly, the state.

The historical roots of these two standards may be traced, respectively, to the Athens and the Jerusalem of antiquity (cf. Lombaard 2011a:74-93). Natural as these ancient 
components of still present liberal-democratic standards seem to us who thrive within them, and imbued with such a sense of worth that lives could be sacrificed in keeping them, three sources (with apologies, Proverbs 30:18-19) may influence us towards less unqualified thought on these matters:

- The recent insistence among theorists of decoloniality that human rights are not universal in any hard sense (cf. e.g. Barreto 2012:1-29);

- The insight among development theorists that the sense of what a good life is cannot with any legitimacy be prescribed (cf. e.g. Sen 2005:3-16); and

- The perspective proposed here, that in distinctive historical contexts, parallel intent, here related to the wellbeing of society, may be sought by discomfitingly - diametrically opposing cultural strategies. In this particular case, such diametrically opposing cultural strategies relate to the role of religion in relation to the laws of a society as it seeks its own wellbeing.

In preparation for developing this last aspect, some free theologising on the relationship between religion and law provides greater context for the insight that will later unfold.

\section{Resonance}

Despite their differences, religion and law as expressions of human life show some notable socio-phenomenological overlaps. These include, among other things, the notion that the social wellbeing of those who share their existence in space and time (geography and temporality) is sought, albeit in at first glance seemingly disconnected ways. Historically, the influences and circumstances that steer religion and law, respectively, to develop in the ways they have are substantively traceable, rendering these two human phenomena, as is the case with everything else about us, conditional and provisional. Such contingency is, however, rendered close to the point of imperceptibility to the broader populace which these two expressions of life aim to serve, by elevating certain aspects of their composition to proportions approximating the supreme, such as "the church" and "the scriptures" in certain religious instances or "the courts" and "the constitution" in certain legal instances. (Initially unintentionally, identifying these parallels was later realised strongly to echo the insights of Schmitt 1922:49-84 and Schmitt 1970:13-98, as acknowledged in Lombaard 2019:1-6.) In a sense indicative of this comparable amplification of status is the intermittent symbolic capitalisation of the spelling of these nouns, respectively as Church, Scripture, Court and Constitution.

Such elevation is not undertaken for the mere sake of power, as critiques of ecclesial and legal systems would have it. The implied authority that comes along in such cases is rather a corollary of the social importance attached to the matters concerned. The stakes are high: protection against injustice and against damnation (cf. Wethmar 1996:473490); the intentions are noble: to be of benefit to the individual and to society. A stark this-worldly - otherworldly distinction between these two service orientations should, however, not be inferred here, since (if the simplification in summary by Ferry 2011:35 may be kept to for a moment) the salvation religion may offer in this understanding is rarely intended to exclude the present, and the justice that law may offer is rarely intended to be transitory. Nor is the latter understood as in principle being free from an almost metaphysical linkage to universal justice or a more clearly metaphysical linkage 
to a divinely willed just arrangement of society. In such an outlook of religion and law, the transcendent and the immanent meet. Historically, albeit imperfectly, law has often and with various degrees of explicitness deferred to God as a final sanction, and in the inverse, religion has often relied on law to ensconce its sanctity and to give concrete effect to its noblest intentions. This occurs despite the at times dismal results in both cases.

Within Christianity, the intricacies of ecclesial law intend to demonstrate, at times tortuously, how the church as the Body of Christ ought according to legal logic carry itself - at least in principle - in love (cf. Jonker 1965). More foundationally, in the New Testament, the Pauline distinction between law and grace (cf. Dunn 1998:128-181) as both fully religious categories in living rightly coram Deo indicated highly influentially the entwinement of rules and faith. Picking up this distinction as it comes to the fore most prominently in the history of the church, the very language of "justification by faith" (cf. e.g. Reid 1992:204-221) emphasised in the Reformation heritage ${ }^{4}$ shows a particular confluence of lawyerly and ministerial ways of thinking. This PaulineCalvinist legacy not infrequently presents itself still in church ministers' devout formulations (perhaps, wranglings) that the faithful live not in freedom from the (Mosaic) law but in freedom unto the law. This kind of theological ambience gives satiated expression to the image of God as judge - a kind of theological metaphor which many find incompatible with the representation of God as love. Certainly, both such theological images are prominently present in the Bible texts, among other depictions. The judicial imagery related to Yahweh is strongly present in what would become the dominant theological stream from exilic Israel onwards (i.e., post $586 \mathrm{BCE}-$ the date of the forced exile of the elite of Jerusalem to Babylon, the events of which had a direct influence on much of the resultant theologised historiography of the Hebrew Bible). These ancient sources include the deuteronomistic lines of historical-theological understanding (compare the royal histories as cast in 1 \& 2 Kings versus 1 \& 2 Chronicles; more comprehensively, compare Joshua to $2 \mathrm{Kings}$ with $1 \mathrm{Chronicles}$ to Nehemiah, as broad indications), understanding of which would come to permeate many Hebrew Bible texts. Thus, the influence on the New Testament, the early and later church, up to current theologies can be traced (implied for instance also in the eschatological dimensions of some ecological theology): there is a God who sits in judgment. Believer beware!

As these diverse though neither thematically nor historically unrelated instances illustrate, God and law in such constructs become related to one another provisionally rather than essentially, namely as a duo of belief and life. The ensuing implied dialogue of Decalogue and existence signifies as a poignant and widely-applied instance the ultimate split infinitive: to be faith-full may now no longer comprise only to be an adherent (as is the case for instance with the patriarchal and, differently, wisdom strands of faith in post-exilic Israel; cf. e.g. Albertz 1992:51-54). Religion now also includes the

In other church traditions, this connection is less prominent, e.g. in Roman Catholicism's placement of salvation within the church (extra ecclesiam nulla salus), in the Lutheran two kingdoms worldview, in the charismatic / Pentecostal traditions' less rationalist and more emotive sense of a future inheritance of the cosmos, etc. 
possibility, in a from then onwards ${ }^{5}$ always present and at times strongly dominant strand of religious expression, that this relationship-of-faith is essentialised as adherence to legitimated practices. Divine will becomes a category of life; to live with God becomes in such thinking predicated on doing rightly by God. Duty attends religion and may become (or absorb) religion. Law rather than God becomes salvific. Statutes become the mediators through which God is encountered (as statues, forbidden for divine representation in ancient Israel, continued to be in other religions). Intimate religious living hence becomes distanced, im-mediate. Codes and codices become the abodes and bodices of faith.

The power of influence of this manner of being religious is difficult to overestimate and persists as a Dawkinsian meme (Dawkins 1976) perpetuating itself across various cultural instances over some two and a half millennia. The stage had for post-exilic Israel been set for religion and legislation, for faith and law, potentially to be placed over against each other in the ensuing Judeo-Christian cultural stream; in more general practice, though, adherence to rules could more easily be defined as religious adherence.

This inferential religiosity plays out also in the inverse, uniquely to modern (i.e. Enlightenment) Western/ised democracies, which have the legislative imperative to separate state and church. Obedience to government laws giving expression to such a separation (which is legislated differently in every democracy and applied with consistency in none) is regarded as being to the benefit of the citizenry, also by believing individuals and religious institutions, doing so often as a sensed duty of faith. The latter socio-political project is specifically undertaken for what is understood to be to the benefit of the societies concerned: for the wellbeing of liberal democracies and their citizens. In time, after the initial French and American constitutions (see below) had grounded these thoughts, which then went on to become part of judicial and educational practice, an alternative within such societies became hardly imaginable to decent citizens (that is, apart from forms of fanaticism that seek distinctly illiberal societies). The reflex position had become that in healthy modern democracies, faith is to be marginalised. Matters religious are excluded from affairs of state; this is for the sake of the good (harmony and/or diversity) of society. The instrument for such a wholesome separation is law, created by the legislature and implemented by the judiciary.

Such is the implied zero position in modern democracies, widely shared in different countries, even if implemented in quite diverse ways. The unstated resonance for a healthy society, the underlying sense of satisfaction for a safely democratic and liberal (i.e., freedom-seeking) society within this frame of reference, is that matters of governance and matters of religious observance ought to be kept distinct. The oil of state machinery and the water of faith should not mix. Law - the legislature and the judiciary - should have no God in it, for the sake of the wellbeing of society as far as (idealtypical) modern democratic convention is concerned.

This is the kind of logic that resonates within all of us who have been schooled in the sensibilities and sensitivities of liberal Western-style democracies.

However, this modern socio-political understanding is also a diametrically opposed

I.e., from the time that the Decalogue is in post-exilic Israel promoted as a defined way of expressing adherence to $\mathrm{YHWH}$, which occurred some time during the exilic or early post-exilic period, i.e. between \pm $550 \mathrm{BCE}$ and $\pm 500 \mathrm{BCE}$. 
cultural strategy to what is found with the early coming-into-being of the Pentateuchal writings of the Hebrew Bible. A prominent historical instance here presents itself as a case in which, precisely for the sake of greater liberty, religion is not omitted from but inserted into the foundational documents of society. This instance will be discussed below.

To take note of such a possibility, of God being injected into law for the sake of liberty (and not primarily related to religious liberty, as a modern take may perhaps instinctively assume, but related to the protection of the political freedom of the populace), is not only historically interesting. In some ways, such a case also helps to lay open to question the present expectation in liberal democracies that it is only without public religious expression that societies may function well, that is, to the benefit of the maximum freedom of the members of that society. Examples of an alternative can thus enlighten current practice, which should in a critical society lead us to rethink how we go about ordering our societies as we continually seek to increase our freedoms.

Such a realisation, in the currently dawning age of post-secularism (cf. Habermas 2008:17-29; Lombaard 2016:1-6 and Lombaard 2015:82-95), is in itself an impulse towards greater liberalism (meant here, as above, in its classic political sense rather than in the poorly informed disparaging sense in which the term liberalism is at times employed within religious circles) intended to serve the greater wellbeing of modern democracies and their citizens.

\section{Rite Right of passage}

In a much more subtle way than is usually drawn from the Hebrew Bible within liberation theology, the sentiment of a "Let my people go" (Exodus 8:1; cf. Luthuli 1962) wish for freedom finds expression in the politically foundational chapter from mid- $7^{\text {th }}$ century BCE Jerusalem, Deuteronomy 13. It is here that we find one of the "seminal ideas" (Ska 2004:146) that had by long-term cultural continuance - the Dawkinsian meme referred to above, although Max Weber's understanding of the influence of ideas (Weber 1905; cf. Otto 2004:181-188) here applies as much - formed and informed the current human rights culture of Western(ised) societies. In the now famous understanding of Deuteronomy 13 by Otto (2002a, drawing on Parpola \& Watanabe 1988), this chapter of Deuteronomy acceded in translation to the enforced neo-Assyrian imperial proclamation, which by means of harsh penalties commanded loyalty to the imperial throne even in the most private of family relationships; that is, this command was issued in fully absolutist terms. The accession was however not bland compliance, but the Hebrew translators in a finely seditious manner succeeded with a cultural rite of passage to a new understanding of the inherent worth of human beings.

Taken as a text on its own, even more so when read with a modern frame of mind, the terminology of Deuteronomy 13 seems befitting to neither a human rights culture nor a Christian culture of love to neighbour and enemy; Deuteronomy 13 hardly reads like an accompanying text in devotional readings from the Sermon on the Mount. The empire-wide binding Assyrian loyalty oath (cf. more broadly, Parpola 1987:161-189) on which Deuteronomy 13 is closely modelled had made clear that the merest murmur of political betrayal of the emperor was punishable by death (below, taken over from Parpola \& Watanabe 1998:34). Read within such a context, the loyalty oath on its own can be understood on its particular (and unforgiving) merits; read against this pre-text, 
Deuteronomy 13 gains a whole new hue.

Some explanatory notes on the text that follows are in order. The left column contains the cuneiform text transliterated into the Latin alphabet. The small sections between square brackets indicate parts of words that had to be reconstructed because of the poor quality of the original cuneiform text. In the Parpola \& Watanabe (1988) English translation in the column to the right, the square brackets parallel these absences, with the normal brackets reserved to include phrases required for the English language metaphor to reflect the intent of the cuneiform writing. The content of this reproduced text here is the prohibition of any act of rebellion or even encouragement of rebellion against emperor Assurbanipal, the mid- $7^{\text {th }}$ century ruler (and one of the last) over the neo-Assyrian empire headquartered in Nineveh, which had Palestine and thus Jerusalem under its power.

Reproduced from Parpola \& Watanabe 1998:34:

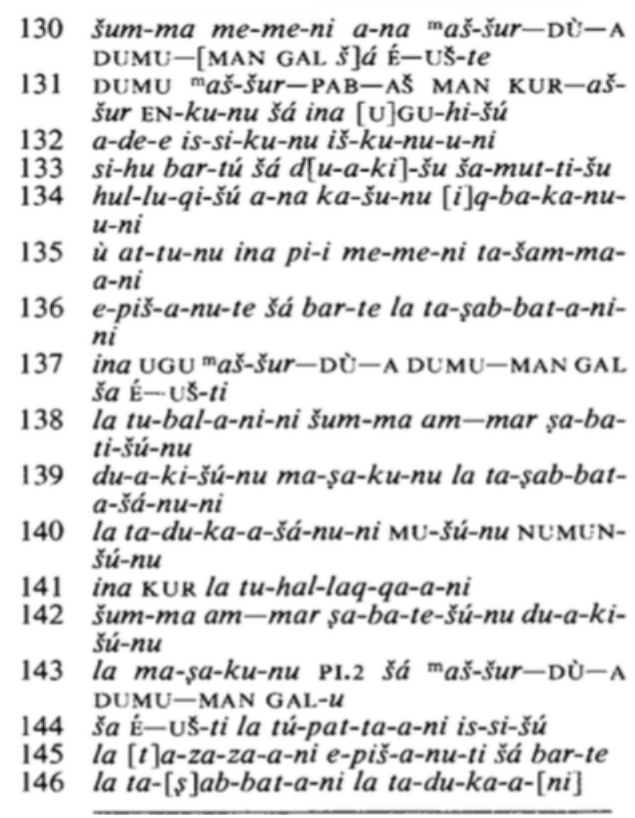

\section{$\S 12$ Action against Those Suborning Treason}

130 If anyone should speak to you of rebellion and insurrection (with the purpose) of ki[lling], assassinating, and eliminating Assurbanipal, the [great crown] prince designate, son of Esarhaddon, king of Assyria, your lord, concerning whom he has concluded (this) treaty with you, or if you should hear it from the mouth of anyone, you shall seize the perpetrators of insurrection, and bring them before Assurbanipal, the great crown prince designate.

138 If you are able to seize them and put them to death, then you shall destroy their name and their seed from the land. If, however, you are unable to seize them and put them to death, you shall inform Assurbanipal, the great crown prince designate, and assist him in seizing and putting to death the perpetrators of rebellion. 
This pre-text, the loyalty oath above, is the text received by the scribes of Deuteronomy 13:2-10, given in what follows (and edited according to Otto 2002b:175; the editing is indicated in italics in the English translation; following also Lombaard 2011a:86):

\begin{tabular}{|c|c|}
\hline $\begin{array}{l}\text { Deuteronomy 13:2-11 } \\
\text { (Biblica Hebraica Stuttgartensia) }\end{array}$ & $\begin{array}{l}=\text { Deuteronomy 13:1-10 } \\
\text { (English Standard Version translation) }\end{array}$ \\
\hline 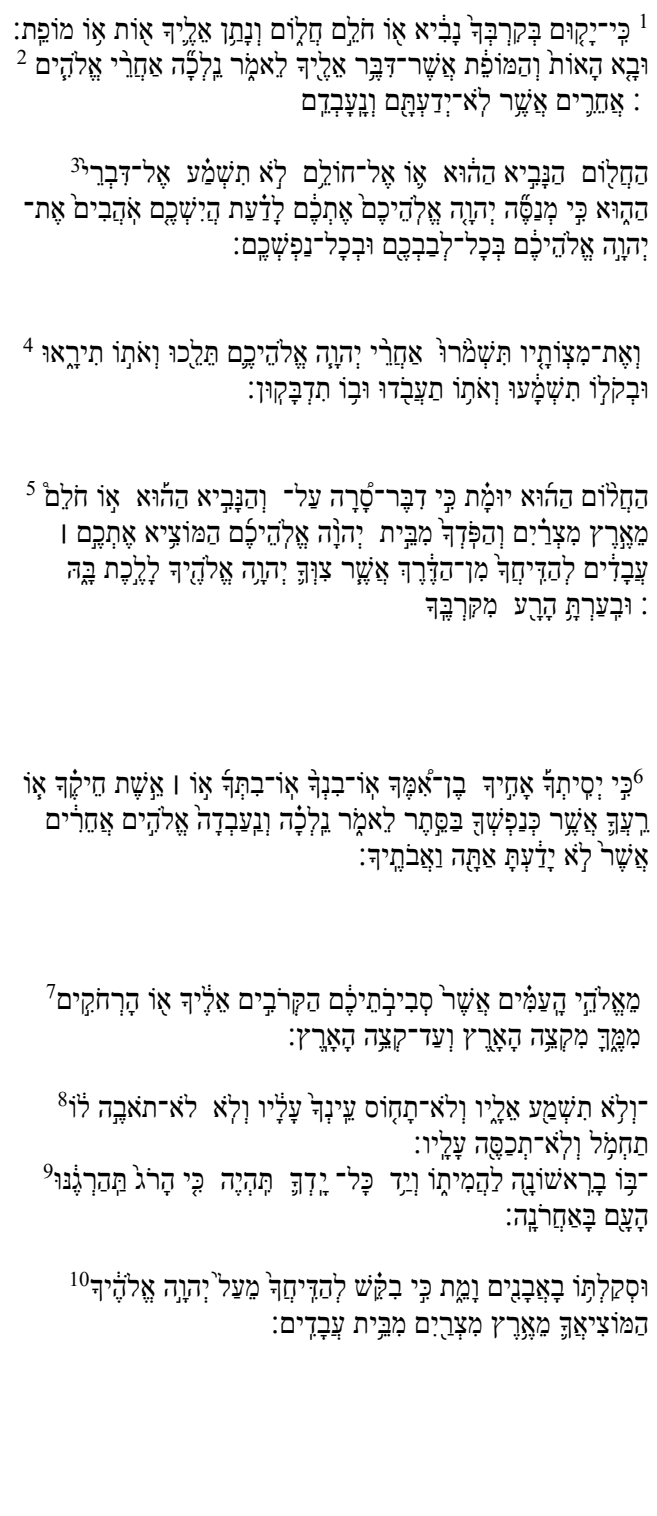 & $\begin{array}{l}{ }^{1} \text { If a prophet or a dreamer of dreams arises } \\
\text { among you and gives you a sign or a wonder, } \\
{ }^{2} \text { and the sign or wonder that he tells you } \\
\text { comes to pass, and if he says, 'Let us go after } \\
\text { other gods, 'which you have not known, 'and } \\
\text { let us serve them,' } \\
{ }^{3} \text { you shall not listen to the words of that } \\
\text { prophet or that dreamer of dreams. For the } \\
\text { LORD your God is testing you, to know } \\
\text { whether you love the LORD your God with all } \\
\text { your heart and with all your soul. } \\
{ }^{4} \text { You shall walk after the LORD your God } \\
\text { and fear him and keep his commandments and } \\
\text { obey his voice, and you shall serve him and } \\
\text { hold fast to him. } \\
{ }^{5} \text { But that prophet or that dreamer of dreams } \\
\text { shall be put to death, because he has taught } \\
\text { rebellion against the LORD your God, who } \\
\text { brought you out of the land of Egypt and } \\
\text { redeemed you out of the house of slavery, to } \\
\text { make you leave the way in which the LORD } \\
\text { your God commanded you to walk. So you } \\
\text { shall purge the evil from your midst. } \\
{ }^{6} \text { If your brother, the son of your mother, or } \\
\text { your son or your daughter or the wife you } \\
\text { embrace or your friend who is as your own } \\
\text { soul entices you secretly, saying, 'Let us go } \\
\text { and serve other gods, which neither you nor } \\
\text { your fathers have known, } \\
{ }^{7} \text { some of the gods of the peoples who are } \\
\text { around you, whether near you or far off from } \\
\text { you, from the one end of the earth to the other, } \\
{ }^{8} \text { you shall not yield to him or listen to him, } \\
\text { nor shall your eye pity him, nor shall you } \\
\text { spare him, nor shall you conceal him. } \\
9 \text { But you shall kill him. Your hand shall be } \\
\text { first against him to put him to death, and } \\
\text { afterward the hand of all the people. } \\
{ }_{10} \text { You shall stone him to death with stones, } \\
\text { because he sought to draw you away from the } \\
\text { LORD your God, who brought you out of the } \\
\text { land of Egypt, out of the house of slavery. }\end{array}$ \\
\hline
\end{tabular}


Regarding this text, some explanatory effort is required to place it within its historical and textual contexts in order to make it easier to understand. Viz., Deuteronomy 13 forms part of the core text of Deuteronomy 12-26 (an intensely edited text), the latter associated with a surprise temple find relayed in 2 Kings 22-23 (a foundational insight in Old Testament scholarship that goes back to De Wette 1805; cf. Otto 2007:321-339). Historically, this surprise find was rather a document constructed as a kind of tractate or confessional or constitution (an easy parallel with modern times eludes us) during the reign of king Josiah, whose reign stretched across a substantial part the second half of the $7^{\text {th }}$ century BCE. The Deuteronomy $12-26$ text preserved in the Hebrew Bible is an extended version of this core document, expanding the contents of this core document "find" through redactional activity, thus reapplying its intent in various later contexts (as had been the practice with all important ancient texts) ${ }^{6}$.

During this period of textual development, the book of Deuteronomy and its theology (the deuteronomistic theology mentioned above) also became demonstrably influential, though not consistently so, across the body of writing, particularly in the creation and redaction of two larger textual corpora of the Hebrew Bible, as is by now standard insights in Old Testament scholarship; here simplified:

- the Torah, or Pentateuch, to which Deuteronomy forms the conclusion in the canonised version of the Bible text: Genesis to Deuteronomy; and

- the Deuteronomistic History, a theological interpretation of the history of ancient Israel based on the core Josianic reformation ideal of fealty to YHWH alone.

This historicised theology had strong political implications too - but as will become clear

6 In outline, the complex coming-into-being of this text of Deuteronomy may be placed within its historicaldevelopmental process, broadly, as follows (graph from Otto 2012:248):

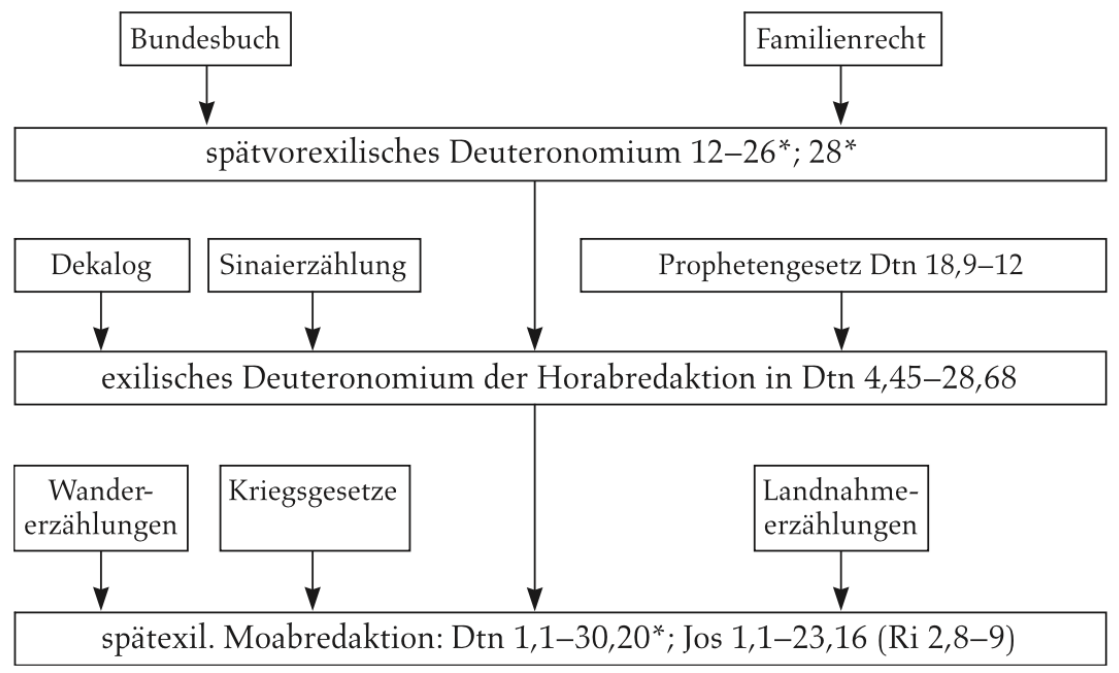


below, that holds some truth for all political orientations to religion, including those on which modern democracies have been built. With Deuteronomy as Archimedean point (the language of, classically, Eissfeldt 1934:188 - with an unexpectedly positive early South African reception in du Plessis 1947 - which has since come into wider use again since Otto 1997:321-339) of the Enneateuch (the first twelve and theologically the most influential books of the Hebrew Bible, stretching from Genesis to 2 Kings $^{7}$ ), the importance of these central chapters in the self-understanding of ancient Israel becomes more evident. Given the cultural-historical influence of the Hebrew Bible throughout Christian Western/ised history, and this includes the nominally non-religious latemodern Western developments from this heritage, the influence (albeit implicit) of these texts on our time ought to be recognised.

That this core part of the Western canon of influential literature is in some sections directly derivative of a neo-Assyrian loyalty oath imposed on an ancient empire (cf. Lombaard 2011b:49-65), yet interpreted anew within Deuteronomy as will become clear below, casts new light on the contingency of our human existence: how we are determined in often unknown ways by our human heritage, current and ancient. With the text of the neo-Assyrian loyalty oath above kept in mind, the at-first-glance exclusively religiously-intolerant Deuteronomy 13 text gains an altogether different colour.

The way in which the neo-Assyrian political system was received was by replacing reverence for the emperor with reverence for God. With this, for the first time in history (as far as we know), the direct relationship of power between ruler and subject is broken by means of - important for the argument here - reference to the divine. That means (quoting here from Lombaard 2011a:86),

not to the king, the verse states in its ancient context, nor to the king's patron deity, as was the case in Mesopotamian royal ideology, but to $Y H W H$ the royal loyalty

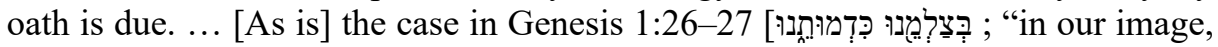

Part of this train of influence has been sketched as follows in Otto (2012:256):

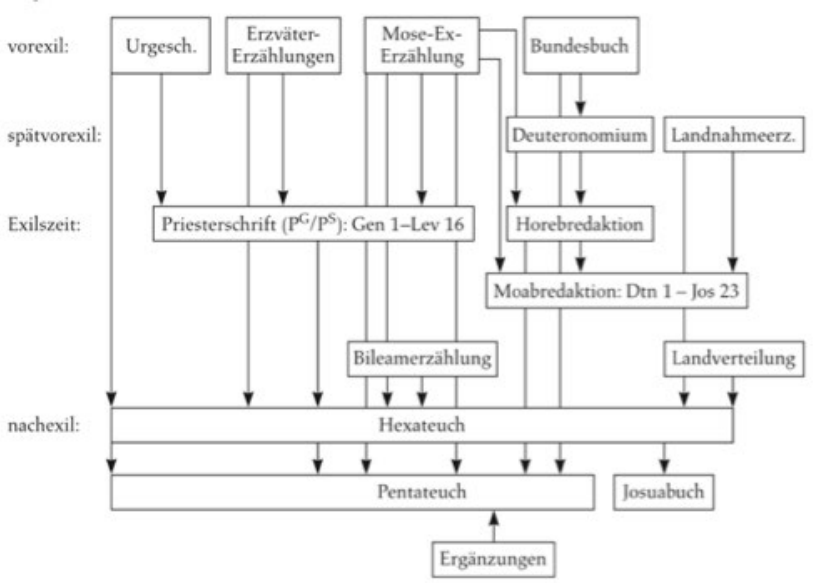

The relationship between these textual corpora remains a major issue in understanding the historical composition of the Hebrew Bible, as can be seen again in e.g. Dozeman, Römer and Schmid (2011). 
in our likeness"], the direct bond between God and citizen is established - a radical political concept for its times...

As indicated by this productive insight by Otto (2002a), this translation-withreinterpretation by the Hebrew scribes in ancient Jerusalem is a fine, delicate move, highly significant when read in its $m$ mid- $^{\text {th }}$-century-BCE socio-political context. Deuteronomy 13 as a (to modern sensibilities) disquieting text had the effect of placing power in the hands of the religious rather than the political leadership. More importantly, the orientation of the citizenry becomes not towards the emperor, as in the first instance, but to God. God is - as it were - inserted between ruler and citizen by the translationwith-reinterpretation strategy in Deuteronomy 13. This is not democratic in the ancient Athenian sense, in which the vox populi becomes a determinative part of political process. However - relating to the second main standard of modern liberal democracy as formulated above, "the protection of the rights of the individual against any encroachment" - Deuteronomy 13 is the beginning of the end of despotism: political power is relativised.

Significantly, God is here a mediating character on the political stage. By God taking front stage, politics become more humanised. The citizenry is now no longer viewed as being directly at the mercy of the ruler. Rather, greater liberty is served by including a religious dimension into the founding document of a society in transition. This religious dimension is a buffer against absolute earthly authority. God becomes a bulwark against the abuse of power.

When compared to the modern situation, elucidated above, a marked contrast presents itself. The impulse here, in Deuteronomy 13, is the precise opposite of what we find in modern liberal democracies, in which the divine is reflexively excluded from political life, avowedly for the sake of the greater wellbeing of the citizenry. In our time, secularisation - in the sense of the purposive exclusion of the religious from public life - is the manner in which the very same outcome is sought: the greater wellbeing of the citizenry. In Deuteronomy 13, in reinterpreting the loyalty treaty to Assurbanipal, the divine is however brought into the picture, doing so for the sake of the greater wellbeing of the citizenry. Here, the monarch is not the fidei defensor, as is the case with the British crown since the dawn of Anglicanism; rather, God is the populi defensor - an almost unimaginable arrangement of the affairs of state in modern liberal democracies. The politics of ancient Israel is deliberately sacrilised for the sake of the common good.

As an aside, this difference between ancient Israel and modern societies is not something unique to this case but has also a philosophical parallel in questions on the existential meaning of life. When in the Hebrew Bible wisdom book of Qoheleth the destructive power of death and the meaninglessness that renders human existence is contemplated, God is kept fully in the picture. When modern existentialist philosophy took that same route of argument, God had to be removed from the scene: only with atheistic assumptions could such meaninglessness be faced in modern philosophy (cf. Lombaard 2009:4).

These are remarkably different cultural moves. By the exact opposite treatment of the divine - inclusion in ancient settings versus exclusion in modern settings - does the metaphysical grounding of the placement of the individual and society make any sense within these respective milieux. 
Returning to the political, in ancient Israel, when law and faith come into interaction, God is put front-of-stage. This, for the sake of the socio-political wellbeing of the society concerned. In modern liberal democracies, for the very same motivation, when law and faith meet, God is placed backstage, behind the curtains. In diametrically opposed cultural strategies, sacralisation in the ancient world and secularisation in the modern world characterise the quest for socio-political wellbeing.

This reflexive difference in cultural strategy can be understood well within the respective socio-historical circumstances. The moment of realisation of this difference is, however, substantively disarming. The different cultural logics at work relativise one approach as as much as the other. In the case of modern liberal democracies, given their inherently self-critical impulses, such a realisation is sobering. The idea of us functioning at a pinnacle of political expression in human history is brought some sense of modesty by this kind of realisation.

As much as the intent here was not to draw a lesson from the Bible for today and even less to imply naively that this example from the Bible should become a model of sorts to which to return or to which to aspire, the insight into this seeming inconsistency in how religion is treated does stimulate reflection. It puts to question perhaps unconsidered notions of what the "correct" way is for law and religion to relate to one another within different political systems.

This kind of philosophical and political reflection additionally also opens up another question on wherein the liberal element of laws lie that would marginalise religion politically. Is some unexamined value perhaps at play here? - some as yet unrecognised core which determines why it would be specifically liberal (again, in the sense of seeking greater freedom) to have as little as possible of this phenomenon of religion around politically? This, whereas with all other aspects of human life, sensitive or not, exclusion of the phenomenon concerned is not the preferred political option by legal means, but rather inclusion, with the trend being towards greater diversity.

Are we, hence, perhaps puppet masters on stage, ventriloquists throwing a voice from somewhere (I take over this metaphor from Lombaard 2001:69-87), unknowingly saying things the audience members hear, but they do not quite know whence the voice comes? And neither do we?

\section{Oh go, all ye faithful?}

To recapture here some of the earlier thoughts and steer them towards their conclusion: the Judeo-Christian-Western/ised cultural stream is unimaginable without a strongly legal component. The idea of "the rule of law" is deeply entrenched. To a substantial extent, the reverse is as intricately indicated: Judeo-Christian impulses had in Western/ised law practices found expression to a great extent prior to the Enlightenment and the dawn of the secular age (on the latter, cf. influentially Taylor 2007). Vestiges of this still remain in modern practice, as we see in for instance official oaths or in force majeure events being described as acts of God. The domains of law and religion remain interwoven in various ways.

Still, the political history of Western/ised societies within the age of modern democracies, marked most clearly by the French and United States constitutions as starting points, has been characterised by a deliberate project of excluding religion from public life by means of law. Although contestation between law and religion is not new 
and is healthy, the deliberate use of one of these phenomena to marginalise the other had never in human history been attempted on such a grand scale, nor so successfully, as had been done in modern democratic statehood. This is different from earlier ages, when by proclamation a particular expression of religiosity could be repressed (as for instance early Christianity had at times been, prior to Constantine) or promulgated as state religion (as Christianity had been from Constantine onwards, in many regions). Neither is this the same as the ideologically-enforced non-religiosity under restrictive societies such as Soviet Communism ${ }^{8}$. In modern, Western/ised democracies - open societies in many respects - the impulse had been that by means of law and state, religion ought to be put on the margins of public life.

In this, the French and American constitutions had been most influential ${ }^{9}$, summarised by the respective concepts of laïcité and the separation of church and state.

Article 1 of the French constitution (1958) reads:

La France est une République indivisible, laïque, démocratique et sociale. Elle assure l'égalité devant la loi de tous les citoyens sans distinction d'origine, de race ou de religion. Elle respecte toutes les croyances. Son organisation est décentralisée.

France shall be a Republic indivisible, secular, democratic and social. It shall ensure the equality before the law of all citizens without distinction of origin, race or religion. It shall respect all beliefs. Its organization shall be decentralised.

The First Amendment to the Constitution of the United States reads as follows:

Congress shall make no law respecting an establishment of religion, or prohibiting the free exercise thereof; or abridging the freedom of speech, or of the press; or the right of the people peaceably to assemble, and to petition the Government for a redress of grievances.

The way these foundational documents of modern democracies across the world has played out with respect to religion in these two societies, and has hence been followed in some ways in wider contexts, has been neither an inclusion of diversity, in the French case, nor neutrality towards religion, in the US case, as had been the respective intentions. Rather, in time, both documents had been employed towards the exclusion of religion from as many instances as possible of public life. To this end, initially unforeseen by the authors of these constitutions, these two foundational documents have been interpreted, and legal steps taken by subsequent generations.

The case could on the basis of these developments strongly be made, then, that despite their intentions to the contrary, these two influential states had in fact not broken any earlier special bond between state and church. Rather, the direction of the earlier special

This example can be productively further explored; here, the cursory reference illustrates the intended point sufficiently.

9 Naturally, many other important instances may be related here. However, historically, these two countries had been the birth places of modern democracies, with their founding documents becoming influential in the founding documents of other democracies. 
bond had simply been reversed, from reflexive inclusion of religion in matters of governance to reflexive exclusion. Religion has thus remained a special case, a human phenomenon amongst all others that has been singled out for special treatment. Such special treatment indicates that a particular bond exists; such a connection has been retained.

Two further aspects could be brought into consideration here, although they are for the main points being made in this contribution less interesting than the argument just put forward. The first is the realisation that an orientation that seeks to be free of all religiosity is in practice a religious orientation. In a similar way as that one cannot fight for pacifism, or a closer example, that one cannot state that to be value-free is value-free, one cannot be a-religious (or stronger: anti-religious) in order to be free of a religious commitment. A-religiosity, or differently put, official atheism, is as much a religious orientation as any other, privileging a certain view on religion above all others. Second, historically speaking, certain earlier thoughts on the separation of church and state had been developed by Martin Luther into practical politics; in breaking the ancient linkage of royalty and the divine, Luther had with the two-kingdoms concept founded a nontheological politic on theological grounds (Malan 2011:56-57). This insight implies at the very least that any a-religious political orientation within the Judeo-ChristianWestern cultural stream has a historical inheritance from religion itself: the idea of the separation of church and state had been theologically constituted.

More foundational for this presentation, though, is the conclusion offered above, that governments that systematically exclude by means of law matters of faith from the ambit of public life have as much a religious commitment as any other. The pretense to be religion-free may be self-soothing, yet the ventriloquism of cross-cultural historical comparison shows up as adherence to some religious master's voice echoing from somewhere. By and large, we do not know what that underlying voice it is, yet we act on it in trying to create socio-political wellbeing within our societies.

\section{BIBLIOGRAPHY}

\section{Albertz, Rainer 1992. Religionsgeschichte Israels in alttestamentlicher Zeit 1}

(Supplements to Das Alte Testament Deutsch/Grundrisse zum Alten Testament

8/1). Göttingen: Vandenhoeck \& Ruprecht.

Atherton, John, Graham, Elaine and Steedman, Ian. 2011. The practices of happiness. Political economy, religion and wellbeing. London: Routledge.

Barreto, José-Manuel. 2012. Decolonial strategies and dialogue in the human rights field: a manifesto, Transnational Legal Theory 3: 1-29

(http://dx.doi.org/10.5235/TLT.3.1.1).

Boer, Roland. 2007. Criticism of Heaven. On Marxism and theology. Leiden: Brill. Bourdieu, Pierre 1986. The forms of capital, in Richardson, J (ed.), Handbook of theory and research for the sociology of education. Westport, CT: Greenwood, 241-258.

Chen, Peter \& Cooper, Cary (eds.). 2014. Wellbeing: a complete reference guide.

Volume III: work and wellbeing. Chichester: Wiley Blackwell.

Cooper, Rachel, Burton, Elizabeth \& Cooper, Cary (eds.). 2014. Wellbeing: a complete reference guide. Volume II: wellbeing and the environment. Chichester: Wiley Blackwell. 
Csikszentmihalyi, M. 1990. Flow. New York: HarperCollins.

Dawkins, Richard. 1976. The selfish gene. New York: Oxford University Press.

De Wette, Wilhelm. 1805. Dissertatio critico-exegetica qua Deuteronomium a prioribus Pentateuchi Libris diversum, alius cuiusdam recentioris auctoris opus esse monstratur. Jena: Universität Jena.

Dodge, Rachel, Daly, Anette, Huyton, Jan, and Sanders, Lalage. 2012. The challenge of defining wellbeing, International Journal of Wellbeing 2(3): 222-235 (doi:10.5502/ijw.v2i3.4).

Du Plessis, Sarel. 1947. Deuteronomium as Archimedespunt van die Pentateuchkritiek (M.Div-verhandeling). Pretoria/Potchefstroom: Universiteit van Suid-Afrika (Potchefstroomse Universiteitskollege vir Christelike Hoër Onderwys).

Dozeman, Thomas, Römer, Thomas \& Schmid, Konrad (eds.). 2011. Pentateuch, Hexateuch, or Enneateuch? Identifying literary works in Genesis through Kings. Atlanta: Society of Biblical Literature.

Dunn, James. 1998. The theology of Paul the apostle. Grand Rapids: W.B. Eerdmans. Eissfeldt, Otto. 1934. Einleitung in das Alte Testament. Tübingen: JCB Mohr (Paul Siebeck).

Ferry, Luc 2011. A brief history of thought. A philosophical guide to living. New York: Harper Perennial.

Fonseca, Xavier, Lukosch, Stephan and Brazier, Frances. 2018. Social cohesion revisited: a new definition and how to characterize it. Innovation, The European Journal of Social Science Research 32(25):1-23.

Gullone, Eleonora \& Cummins, Robert 2002. Editorial - The Universality of Subjective Wellbeing, in Gullone, Eleonora \& Cummins, Robert (eds) The universality of subjective wellbeing indicators. A multi-disciplinary and multinational perspective. Dordrecht: Springer Science+Business Media, 5-6.

Habermas, Jürgen 2008. Secularism's crisis of faith: Notes on post-secular sciety, New Perspectives Quarterly 25: 17-29.

Huppert, Felicia \& Cooper, Cary (eds.). 2014. Wellbeing: A complete reference guide. Volume VI: Interventions and policies to enhance wellbeing. Chichester: Wiley Blackwell.

Joas, Hans. 2013. The sacredness of the person: a new genealogy of human rights. Washington, DC: Georgetown University Press.

Jonker, Willie. 1965. Om die regering van Christus in sy kerk. Intreerede by die aanvaarding van die professoraat in Teologie by Unisa (Mededelinge van Unisa A19). Pretoria: University of South Africa.

Kirkwood, Thomas \& Cooper, Cary (eds.). 2014. Wellbeing: A complete reference guide. Volume IV: Wellbeing in later life. Chichester: Wiley Blackwell.

Landry, Susan \& Cooper, Cary (eds.). 2014. Wellbeing: A complete reference guide. Volume I: Wellbeing in children and families. Chichester: Wiley Blackwell.

Lessing, Gotthold Ephraim. 1777. Über den Beweis des Geistes und der Kraft. In Göpfert, Herbert (ed.), 1979, Werke, 8. Bd.: Theologiekritische Schriften III, Philosophische Schriften. München: Hanser Verlag, 9-14.

Le Roux, Jurie. 1997. Our historical heritage, Old Testament Essays 10(3): 401-423

Le Roux, Jurie. 1993. The nature of historical understanding (or: hermeneutics and history), Studia Historiae Ecclesiasticae XIX/1:35-63. 
Lombaard, Christo. 2019. Weighing Schmitt's political theology anew: Implicit religion in politics, HTS Teologiese Studies/Theological Studies 75(3): 1-6.

Lombaard, Christo. 2016. Sensing a "second coming": An overview of new concepts in sociology, philosophy, law and theology on the re-emerging religious in private and public life, Verbum et Ecclesia 37(1): 1-6.

Lombaard, Christo. 2015. "And never the twain shall meet"? Post-secularism as newly unfolding religio-cultural phase and Wisdom as ancient Israelite phenomenon. Spiritualities and implications compared and contrasted, Journal of Theology for Southern Africa 152: 82-95.

Lombaard, Christo. 2011a. Biblical spirituality and human rights, Old Testament Essays 24(1): 74-93.

Lombaard, Christo. 2011b. No empire, no Bible? Aspects of the relationship between biblical texts and current anti-empire views, Studia Historiae Ecclesiasticae XXXVII: 49-65.

Lombaard, Christo. 2008. Problems of narratological analyses of Genesis 22:1-19. In Augustin, M and Niemann, HM (eds.), Thinking towards new horizons. Collected communications to the XIX ${ }^{\text {th }}$ congress of the International Organization for the Study of the Old Testament, Ljubljana 2007 (Beiträge zur Erforschung des Alten Testaments und des Antiken Judentums 55). Bern: Peter Lang, 49-62.

Lombaard, Christo. 2009. Two approaches to life in the Second Temple period: Deuteronomy and Qoheleth, HTS Theological Studies 65(1): 1-6.

Lombaard, Christo. 2001. The Bible in the apartheid debate. In Hofmeyr, Hoffie, Lombaard, Christo and Maritz, Petrus (eds.), $1948+50$ years. Theology, apartheid and church: Past, present and future (Perspectives on the Church / Perspektiewe op die Kerk, Series 5: Vol. 1). Pretoria: IMER (Institute for Missiological and Ecumenical Research), University of Pretoria, 69-87. Luthuli, Albert 1962. Let my people go. An autobiography. London: Collins. Malan, Koos. 2011. Politokrasie. ' $n$ Peiling van die dwanglogika van die territorial staat en gedagtes vir ' $n$ antwoord daarop. Pretoria: Pretoria University Law Press.

McDaid, David and Cooper, Cary (eds.). 2014. Wellbeing: A complete reference guide. Volume V: The economics of wellbeing. Chichester: Wiley Blackwell.

Morris, Christopher. 1999. The social contract theorists. Critical essays on Hobbes, Locke, and Rousseau. Lanham, Md.: Rowman \& Littlefield.

Otto, Eckart. 2012. Deuteronomium 1-11. Erster Teilband: 1,1-4,43. Freiburg im Breisgau: Verlag Herder GmbH.

Otto, E. 2007. Das Deuteronomium als archimedischer Punkt der Pentateuchkritik. Auf dem Wege zu einer Neubegründung der De Wette'schen Hypothese. In Vervenne, Marc and Lust, Johan (eds.), Deuteronomy and deuteronomic literature (Festschrift CHW Brekelmans). Leuven: Uitgeverij Peeters, 321-339.

Otto, Eckart. 2004. 'Wer wenig im Leben hat, soll viel im Recht haben': Die kulturhistorische Bedeutung der Hebräischen Bibel für eine moderne Sozialethik. in Levinson, Bernard and Otto, Eckart (eds.), Recht und Ethik im Alten Testament (Altes Testament und Moderne 13). Münster: LIT Verlag, 181-188. 
Otto, Eckart. 2002a. Gottes Recht als Menschenrecht. Rechts- und literaturhistorische Studien zum Deuteronomium (Beihefte zur Zeitschrift für altorientalische und biblische Rechtsgeschichte, Band 2). Wiesbaden: Harrassowitz Verlag.

Otto, Eckart. 2002b. Gerechtigkeit in der orientalischen und okzidentalen Antike. Aspekte für den ethischen Diskurs in der Moderne im Spannungsfeld zwischen Max Weber und Ernst Troeltsch. In Gestrich, Christoph (ed.), Die Aktualität der Antike: das ethische Gedächtnis des Abendlandes. Berlin: Wichern, 44-60.

Parpola, Simo. 2004. National and ethnic identity in the Neo-Assyrian Empire and Assyrian identity in post-empire times, Journal of Assyrian Academic Studies 18(2): 5-22.

Parpola, Simo and Watanabe, Kazuko. 1988. Neo-Assyrian treaties and loyalty oaths (State Archives of Assyria II). Helsinki: University of Helsinki Press.

Parpola, Simo. 1987. Neo-Assyrian treaties from the royal archives of Nineveh, Journal of Cuneiform Studies 39(2): 161-189.

Rawls, John. 1971. A theory of justice. Cambridge, Mass.: Harvard University Press.

Reid, Stanford. 1992. Justification by faith according to John Calvin. In Gamble, Richard (ed.), An elaboration of the theology of Calvin. New York: Garland, 204221.

Schmitt, Carl. 1970 (2008). Politische Theologie II. Die legend von der Erledigung jeder politischen Theologie (5. Auflage). Berlin: Duncker \& Humblot.

Schmitt, Carl. 1922 (1934). Politische Theologie. Vier Kapitel zur Lehre von der Souveränität (2. Auflage). München: Verlag Von Duncker \& Humblot.

Sen, Amartya. 2005. Development as capability expansion, in Fukuda-Parr, Sakiko and Kumar, Shiva (eds.), Readings in human development. New Delhi: Oxford University Press, 3-16.

Ska, Jean-Louis. 2004. Biblical law and the origins of democracy. In, Brown, Wiliam (ed.), Pages in the Ten Commandments: the reciprocity of faithfulness. Louisville: Westminster John Knox Press, 146-158.

Taylor, Charles. 2007. A secular age. Cambridge, MA: Harvard University Press.

Thiselton, Anthony. 1992. New horizons in hermeneutics. Grand Rapids: Zondervan Publishing House.

Van der Ven, Johannes, Dreyer, Jaco and Pieterse, Hennie. 2004. Is there a God of human rights? The complex relationship between human rights and religion: a South African case. Leiden: Brill.

Van Huyssteen, Wentze.1 2006. Alone in the world? Human uniqueness in science and theology. Grand Rapids: William B. Eerdmans Publishing Company.

Verhoef, Anné. 2014. Sisyphus, happiness and transcendence, South African Journal of Philosophy 33(4): 537-546.

Weber, Max. 1905. Die protestantische Ethik und der "Geist" des Kapitalismus, Archiv für Sozialwissenschaft und Sozialpolitik 21: 1-110.

Wethmar, Conrad. 1996. Wat het Athene met Jerusalem te doen? Enkele historiessistematiese gesigspunte in verband met die vraag of die teologie aan die universiteit tuishoort, Skrif en Kerk 17(2): 473-490. 